\title{
膀胱尿管逆流現象の臨床的検討
}

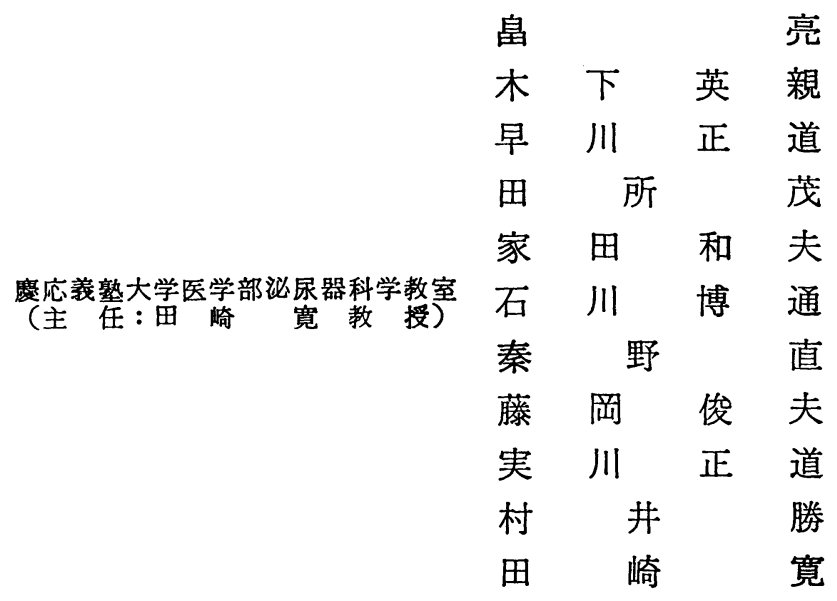

\section{CLINICAL STUDY ON VESICOURETERAL REFLUX}

Makoto Hata, Hidechika Kinoshita, Masamichi Hayakawa, Shigeru Tadokoro,

Kazuo Ieda, Hiromichi Ishikawa, Tadashi Hatano, Toshio Fujioka,

Seido Jitsukawa, Masaru Murai and Hiroshi Tazaki

Department of Urology, School of Medicine, Keio University

(Director: Prof. Hiroshi Tazaki)

A clinical study of 73 patients with vesicoureteral reflux is presented.

Between 1968 and 1977, we saw 73 patients, ranging in age from 4 months old to 73 years old, with vesicoureteral reflux (24 males and 49 females), which formed $2.1 \%$ of the total number of inpatients admitted to Urology service during the same period. Of the 73 patients, 46 had primary vesicoureteral reflux and the remaining 27 had secondary vesicoureteral reflux. Of the 46 patients with primary vesicoureteral reflux, 35 patients were female and 11 were male (female/male $=3: 1$ ). The age distribution of the female patients showed a high incidence in patients less than 10 years of age and in their twenties and thirties, whereas that of male patients showed a high incidence in patients less than 10 years of age. Primary vesicoureteral reflux was relatively uncommon in male adults, the age of the oldest patients being 33 years old.

The operation for affected ureters was performed on 37 patients (51 ureters) with primary vesicoureteral reflux and 7 patients $(7$ ureters) with secondary vesicoureteral reflux. As a surgical operation for patients with primary vesicoureteral reflux, Politano-Leadbetter procedure was performed in 26 patients ( 36 ureters), Paquin procedure in 8 patients (12 ureters), and nephrectomy in 2 patients. Also there was a uretero-ureterostomy in one patient who had a unilateral complete double ureter and the refluxing ureter was united to its party. Of the patients with primary vesicoureteral reflux who underwent either Politano-Leadbetter or Paquin procedure and were followed more than one year, 23 patients had no radiological evidence of vesicoureteral reflux (satisfactory operative result) and one had a poor result with formation of a ureteral stricture at the site of repair, making the success rate 97.3\%. Both Politano-Leadbetter and Paquin procedure seemed to be epually good in 
terms of the ease with which the procedure could be performed and the effectiveness to eliminate vesicoureteral reflux. There was no occurrence of vesicoureteral reflux on contralateral ureters after unilateral operation.

Of the 7 patients with secondary vesicoureteral reflux, Politano-Leadbetter procedure and Paquin procedure were performed in epual number of patients (3 patients) and nephrectomy in one patient.

Based on our experiences as well as review of the literature, it is our rule to consider primarily surgical correction for all adult primary vesicoureteral reflux, including sterile vesicoureteral reflux.

\section{緒言}

非閉塞性尿路感染症の患者を対象にして積極的に膀胱 造影を行ってみると小児では約 $50 \%$, 成人でも10\%に膀 胼尿管逆流現象（以下 VUR）が証明されるといわれ る゙。これを放置して括けば腎孟腎炎を繰返して，つい には末期腎不全の原因ともなる2．一方正しい適応のも とに手術を行えば，手術成績はほぼ100\%に近く，泌尿 器科領域のなかでも外科的手術療法がもつとも奏効する 疾患の一つであり，その発生頻度が稀れでないことを考 えあわせるとその臨床的意義は大きい，慶大泌尿器科学 教室では過去10年間に73例の VUR を経験したので臨床 的検討を行い，文献的考察を加えて報告する.

\section{研究対象}

1968年 1 月より1977年12月までの 10 年間に慶大泌尿器 科に入院した3,551名のらち VUR 症例は73名 $(2.1 \%)$ であった. 年度別患者数をみると，ここ数年増加の傾向 が見られるが，これはVUR に対する認識がたかまつて きたことを反映しているものであろう（図1），症例は

Fig. 1 No. of Patients per Year

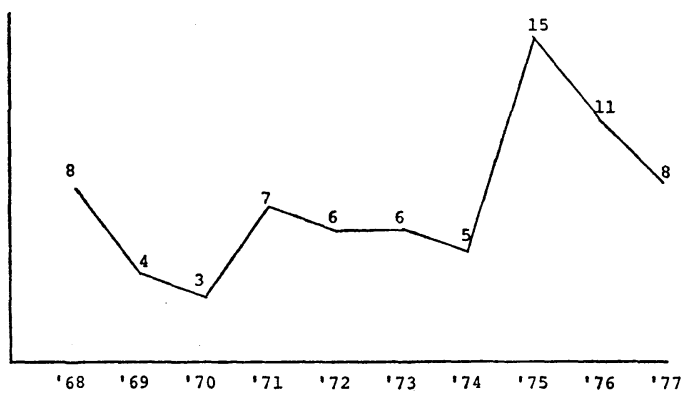

男子 24 名, 女子 49 名からなり，年齢は生後 4 カ月から 75 歳まで分布した. 非閉塞性の primary VUR が46例, 他 に原因疾患のある secondary VUR が27例であつた（表 1). 男女比は primary VUR で3：1 と女子に多いが, secondary VUR ではほとんど性差はなかつた．年龄分 布は primary VUR では女子に打いて10歳以下と20 40
Table 1

\begin{tabular}{c|c|c|c}
\hline & Male & Female & Total \\
\hline $\begin{array}{c}\text { Primary } \\
\text { VUR }\end{array}$ & 11 & 35 & 46 \\
\hline $\begin{array}{c}\text { Secondary } \\
\text { VUR }\end{array}$ & 13 & 14 & 27 \\
\hline Total & 24 & 49 & 73 \\
\hline
\end{tabular}

Table 2 Primary Diseases of Secondory VUR

\begin{tabular}{l|c|c|c}
\hline & Male & Female & Total \\
\hline BPH & 6 & 0 & 6 \\
\hline Neurogenic bladder & 2 & 4 & 6 \\
\hline Tuberculosis & 3 & 1 & 4 \\
\hline Post ureterocystoneostomy & 0 & 3 & 3 \\
\hline Post hysterectomy & 0 & 2 & 2 \\
\hline Urethral stricture & 0 & 2 & 2 \\
\hline Bladder tumor & 0 & 1 & 1 \\
\hline Bladder neck contracture & 0 & 1 & 1 \\
\hline Posterior urethral valve & 1 & 0 & 1 \\
\hline Phimosis & 1 & 0 & 1 \\
\hline \multicolumn{1}{c|}{ Total } & 13 & 14 & 27 \\
\hline
\end{tabular}

Table 3 Side of Affected Ureters

\begin{tabular}{c|c|c|c|c} 
& Right & Left & Bilateral & Solitary \\
\hline $\begin{array}{c}\text { Primary } \\
\text { VUR }\end{array}$ & 11 & 15 & 19 & 1 \\
\hline $\begin{array}{c}\text { Secondary } \\
\text { VUR }\end{array}$ & 9 & 11 & 4 & 3 \\
\hline Total & 20 & 26 & 23 & 4 \\
\hline
\end{tabular}

歳にピークをもつ 2 栄性, 男子においては10歳以下に ピークをもつ 1 峯性の分布をしめした．男子の成人例は 少なく最高は33歳であつた (困 2). Secondary VUR で は男子の場合60歳以上が圧倒的に多く，原疾患は前立腺 肥大症が多かつた. 女子の場合は各年踰層に均等に分布 しておうり，原疾患も神経因性膀脱をはじめとして多種に わたつた（表 2 ）．罹患尿管の 左右差はほとんどなく， 
Fig. 2 Age Distribution

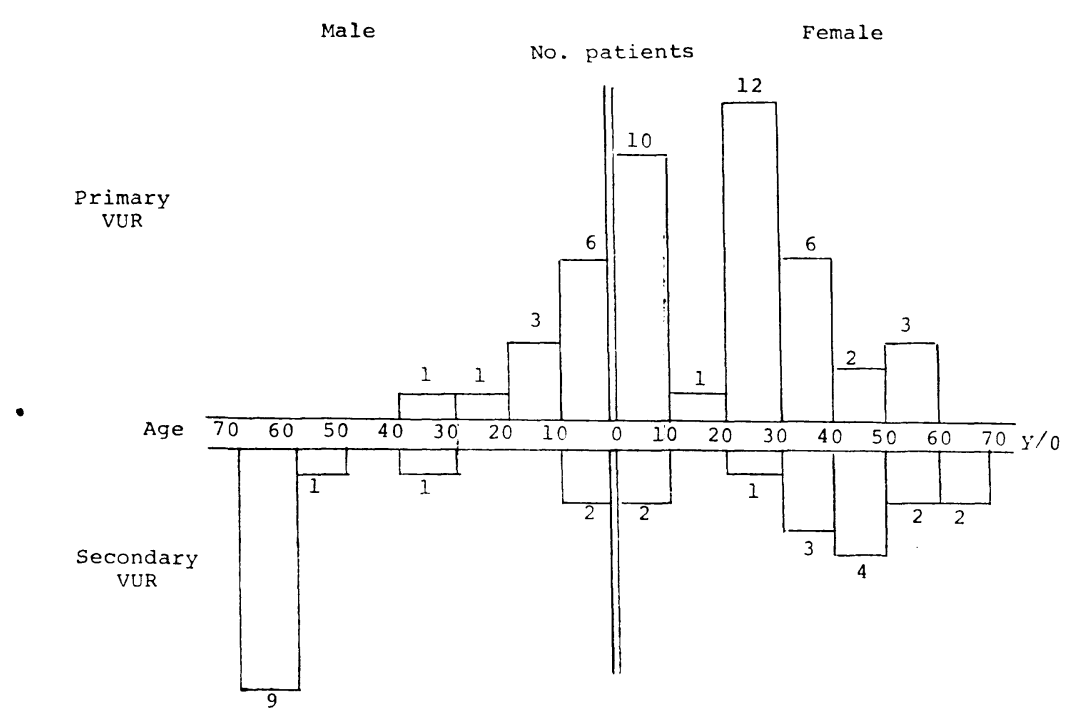

primary VUR では両側性のものが比較的多くて42\%を 占めた。な拊他の原因で腎摘されたあとの単腎に発生し たものが primary VUR に 1 例, secondary VUR に 3 例 含まれていた（表 3 ）.

\section{臨床症状}

初発症状ならびに初診時理学的所見について検討して

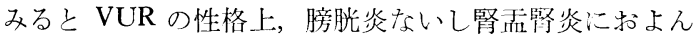

Table 4 No. of Patients Presenting with Various Symptoms

\begin{tabular}{l|c|c}
\hline & $\begin{array}{c}\text { Primary } \\
\text { VUR }\end{array}$ & $\begin{array}{c}\text { Secondary } \\
\text { VUR }\end{array}$ \\
\hline Chill \& Fever & $29(6)$ & $6(1)$ \\
\hline Bacteriuria & $17(1)$ & $11(0)$ \\
\hline Cloudiness of urine & $15(1)$ & $9(0)$ \\
\hline Renal pain & $11(0)$ & $4(0)$ \\
\hline Recurrent cystitis & $9(2)$ & $1(1)$ \\
\hline CVA tenderness & $9(0)$ & $1(0)$ \\
\hline Albuminuria & $4(3)$ & 0 \\
\hline Microhematuria & $4(2)$ & $1(0)$ \\
\hline Macrohematuria & $3(0)$ & $6(4)$ \\
\hline Dysuria & 0 & $5(1)$ \\
\hline Urinary frequency & $1(0)$ & $3(2)$ \\
\hline Uremia & $1(1)$ & $2(0)$ \\
\hline
\end{tabular}

( ) No. of patients presenting with single symptom
ではじめて自覚的, 他覚的にとら兄られるとが多いの で，当然ながら悪寒，発熱，尿こんだく，細菌尿，腎蔵 部自発痛などの炎症性徴候が多くなる（表4）。Bacteriuria が証明された症例での起炎菌は E. coli が約半数を 占めたが，病気の性格上長期間にわたる経過をとり，来 院時すでに化学療法をうけているものがあり, E. coli 以 外の多種の起炎菌が証明されることも多い（表 5 ）。一 方 primary VUR では蛋白尿と顕微鏡的血尿を初発症状 とした症例がそれぞれ 4 例ずつあり，ちち 3 例と 2 例は 自覚的に全く無症状で健康診断によつて蛋白尿，あるい

Table 5 Patients presented with bacteriuria

\begin{tabular}{l|c|c}
\hline \multirow{2}{*}{ Organism } & \multicolumn{2}{|c}{ No. Patients } \\
\cline { 2 - 3 } & Primary VUR & Secondary VUR \\
\hline E. Coli & 8 & 6 \\
\hline Staphylococcus & 2 & 1 \\
\hline Proteus & 1 & 0 \\
\hline Klebsiella & 1 & 1 \\
\hline Enterobacter & 1 & 1 \\
\hline Pseudomonas & 1 & 1 \\
\hline Serratia & 0 & 1 \\
\hline Unknown & 3 & $12^{*}$ \\
\hline Total & 17 & 1 \\
\hline
\end{tabular}

* two organisms grew in the urine from one patient 
Fig. 3 Case 1. Preogerative IVP

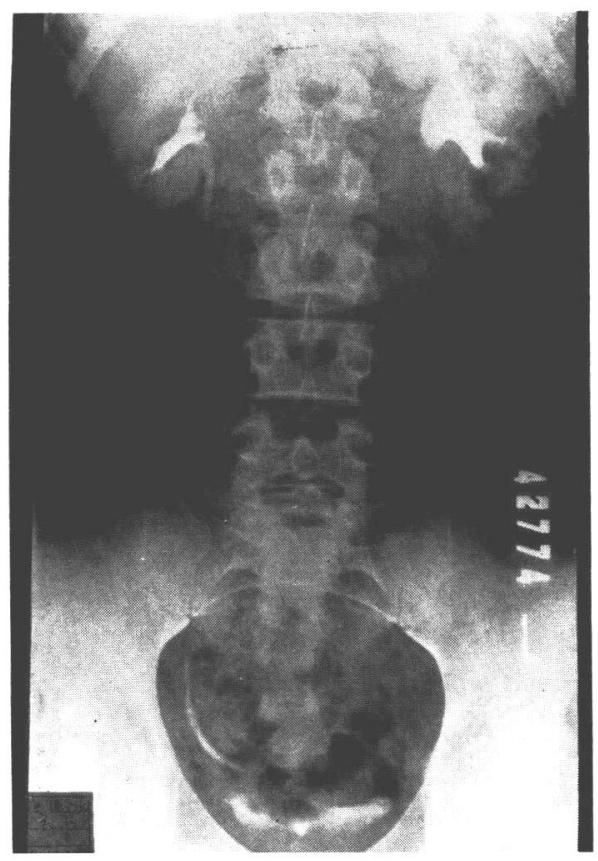

Fig. 5 Case 1. Postoperative IVP

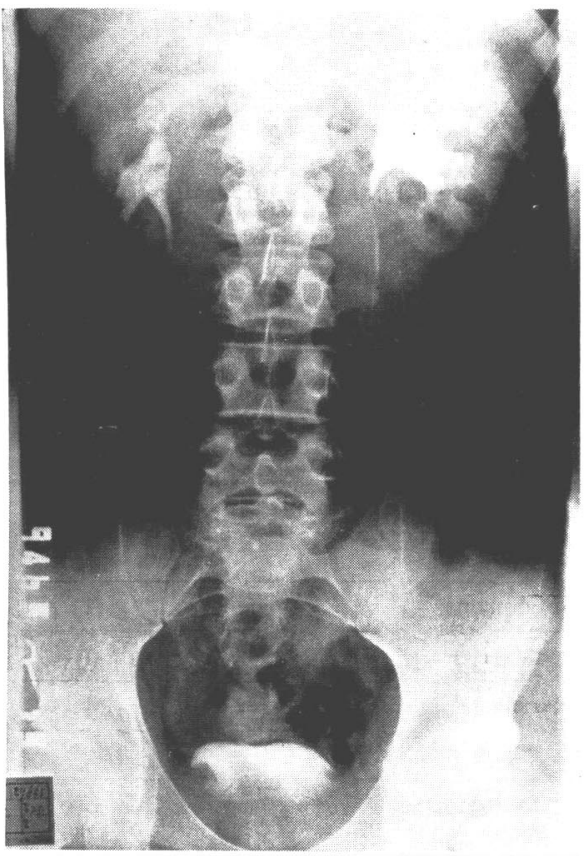

Fig. 4 Case 1. Preoperative voiding cystogram

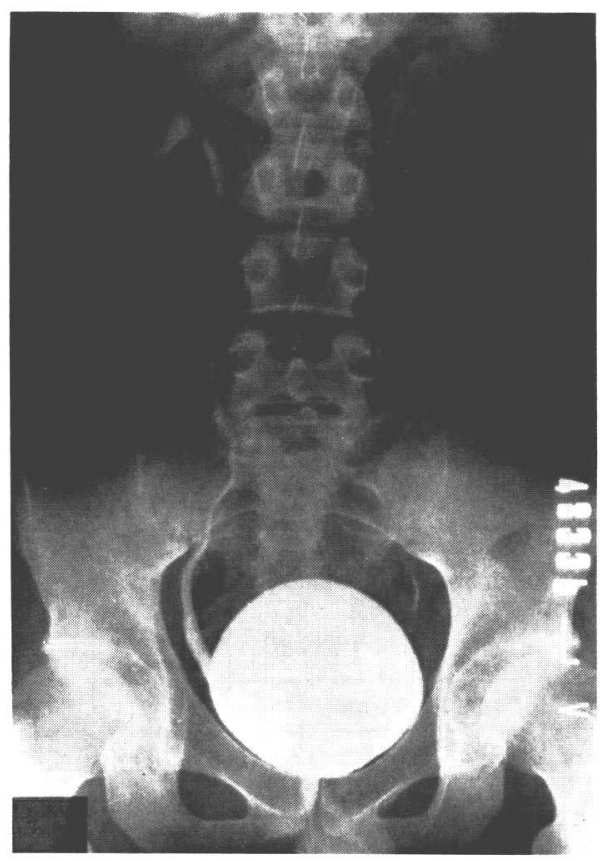

Fıg. 6 Case 1. Postoperative voiding cystogram

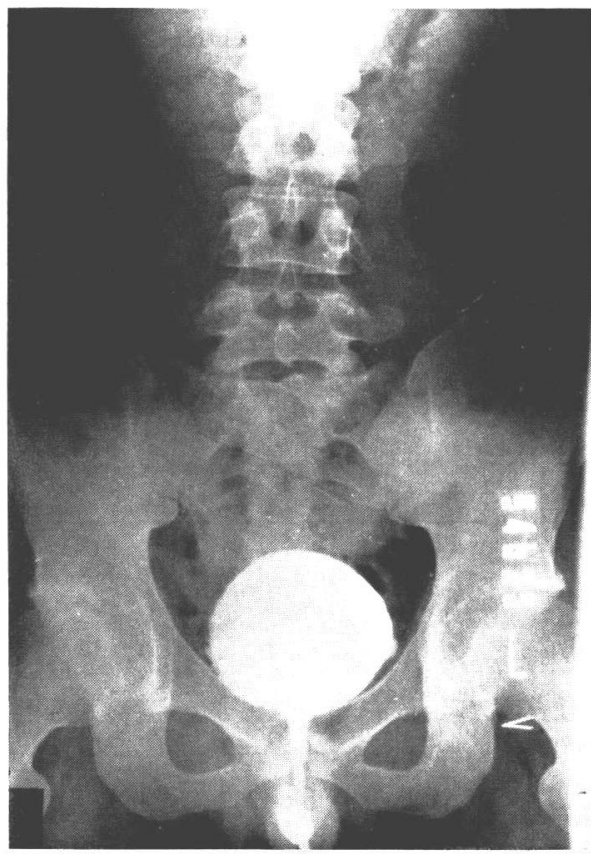


は血尿を指摘されて泌尿器科依頼 となりはじめて VUR が発見されたものである。これらはいずれも若年者症例 で, 後述する IVP 所見も軽徵であり, VUR 早期発見 の一徵候として注目に值するものであつた。

症例 $1 ： 21$ 歳男子大学生, 健康診断にて顕微鏡的血尿 を指摘され，慶大泌尿器科に紹介された，自覚症状は全 くなかったＩVP 上わずかに左腎孟の払張像が見られ るだけであつたが（図 3)，排尿時膀胱造影（以下 VCG） で grade I と II の両側性 VUR が証明された（図4). 両側 Politano-Leadbetter 法にて逆流防止手術を施行し たが，術後腎機能は良好で（図 5)，VUR の消失（図 6)とともに顕微鏡的血尿もみられなくなつた。

\section{術前 $\mathbf{X}$ 線学的検查}

術前の IVP について詳細な検討を行い得た primary VUR 52尿管のうち全く異常なしと読影されたものは 7 尿管で，のこり45尿管には何らかの 異常が指摘され た。 もつとも多い所見は慢性腎孟腎炎による calyceal scarring で31尿管にみられた。ついで hydronephrosis 19 尿管 hydroureter 18尿管であるが，明らかに払張のみら れる場合には同時に calyceal scarringをともなつてい た．尿管が全長にわたつて描出される像は10尿管に㧤い て観察されたが，うち 6 尿管は軽度の hydroureter をと あならのみであり，早期の VUR を発見するのに重要な IVP 所見であると考えた. VUR がすすみ腎盂，尿管の 払張が高度になると生理的狭窄に機能的狭窄が加わつて IVP 上，腎孟尿管移行部狭窄 (UPJ stricture) あるいは 尿管膀胱移行部狭窄 (UVJ stricture) が見られるように なるが，われわれのシリーズではそれぞれ 3 尿管と 2 尿 管に見られただけで比較的少数であつた。ほかに後部尿 道に開口する異所開口尿管と, 完全重複尿管の一方に発 生した VUR がそれぞれ 1 尿管ずつと，萎縮腎にともな つたもの 2 尿管が含まれていた。一方 secondary VUR の術前 IVP 所見も primary VUR のそれと本質的に異 なるものではなかつた（表 6 ).

VUR の診断を目的とした膀胖造影はつぎのように行 つた.すなわち $15 \%$ ヨウ化ナトリウムを，内筒をはずし て尿道カテーテルに垂直に接続した浣腸器から, 落差 で入る最高量を注入した。この時点で証明される逆流 を low pressure VUR とし, 尿道カテーテル拔去後, 排尿時のものを high pressure VUR とした。 こうして Dwoskin \& Perlmutter の判定基準 ${ }^{3)}$ にしたがつて grade を決めた76尿管について検討を加えた（表 7). Low pressure で証明される VUR には grade の低いものか
Table 6 Abnormal findings of pre-operative IVP (No. of Ureters).

\begin{tabular}{l|c|c}
\hline & $\begin{array}{c}\text { Primary } \\
\text { VUR }\end{array}$ & $\begin{array}{c}\text { Secondary } \\
\text { VUR }\end{array}$ \\
\hline Absent & 7 & 5 \\
\hline Present & 45 & 21 \\
\hline Pyelonephritis & 31 & 10 \\
\hline Hydronephrósis & 19 & 11 \\
\hline Hydroureter & 18 & 8 \\
\hline $\begin{array}{l}\text { Visualization of } \\
\text { entire ureter }\end{array}$ & 10 & 7 \\
\hline UPJ stricture & 3 & 0 \\
\hline UVJ stricture & 2 & 1 \\
\hline Ectopic ureter & 1 & 0 \\
\hline Double ureter & 1 & 1 \\
\hline Contracted kidney & 2 & 1 \\
\hline Non visualized kidney & 0 & 1 \\
\hline
\end{tabular}

Table 7 VUR Grading (No. of Ureters)

\begin{tabular}{c|l|r|r|r|r|r}
\hline \multirow{2}{*}{} & & \multicolumn{5}{|c}{ Grade } \\
\cline { 2 - 7 } & 1 & 2 & 3 & 4 & Total \\
\hline \multirow{4}{*}{$\begin{array}{c}\text { Primary } \\
\text { VUR }\end{array}$} & low pressure & 6 & 4 & 8 & 4 & 22 \\
\cline { 2 - 7 } & high pressure & 12 & 10 & 7 & 0 & 29 \\
\cline { 2 - 7 } & sub total & 18 & 14 & 15 & 4 & 51 \\
\hline \multirow{3}{*}{$\begin{array}{c}\text { Secondary } \\
\text { VUR }\end{array}$} & low pressure & 3 & 1 & 7 & 4 & 15 \\
\cline { 2 - 7 } & high pressure & 6 & 2 & 2 & 0 & 10 \\
\cline { 2 - 7 } & sub total & 9 & 3 & 9 & 4 & 25 \\
\hline \multicolumn{2}{c|}{ Grand Total } & 27 & 17 & 24 & 8 & 76 \\
\hline
\end{tabular}

ら高いものまであるが, high pressure ではじめて証明さ れる VUR には grade の低いものが多く，この傾向は primary VUR と secondary VUR の両方に共通してい た。

\section{尿管口の形態と VUR}

膀胱鏡的に62尿管口の形態を観察し, Lyon et al ${ }^{4)}$ の 記述にしたがつて 4 型に分類した（表 8). Primary VUR 46尿管と secondary VUR 16尿管が含まれていた が，そのうち38尿管と15尿管について尿管口の形態と VUR の grade との相関について検討した（表 $9 ， 10$ ).

Primary VUR では概観して grade の低い場合には正 常の尿管口に近いものが多く, grade の高い場合には golf hole に近ずく傾向はあるが，個々の症例にあたつ 
Table 8 Configuration of ureteral orifice \& VUR (No. of Ureters)

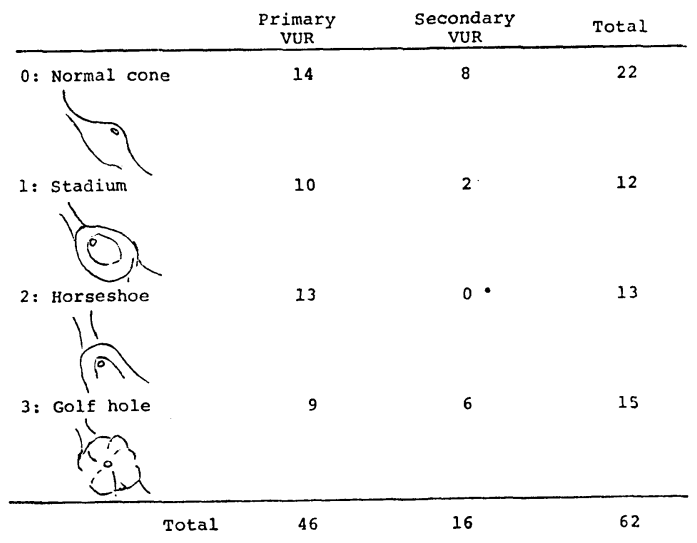

Table 9 Correlation between VUR Grading \& Ureteral Orifice (No. of Ureters in Primary VUR)

\begin{tabular}{l|c|c|c|c}
\hline \multirow{2}{*}{ Configulation } & \multicolumn{4}{|c}{ VUR Grading } \\
\cline { 2 - 5 } & 1 & 2 & 3 & 4 \\
\hline $0:$ Normal cone & 8 & 2 & 2 & \\
\hline $1:$ Stadium & 6 & 3 & 1 & \\
\hline $2:$ Horseshoe & 4 & 3 & 1 & 1 \\
\hline $3:$ Golf hole & & 2 & 3 & 2 \\
\hline
\end{tabular}

Table 10 Correlation between VUR Grading \& Ureteral Orifice (No. of Ureters in Secondary VUR)

\begin{tabular}{l|c|c|c|c}
\hline \multirow{2}{*}{ Configulation } & \multicolumn{4}{|c}{ VUR Grading } \\
\cline { 2 - 5 } & 1 & 2 & 3 & 4 \\
\hline $0:$ Normal cone & 6 & 1 & 1 & \\
\hline $1:$ Stadium & & 1 & & \\
\hline $2:$ Horseshoe & & & & \\
\hline $3:$ Golf hole & & & 5 & 1 \\
\hline
\end{tabular}

て尿管口の形態から VUR の grade を推論することに は無理があると考兄られた。一方 secondary VUR では 尿管口の形態と VUR の grade には比較的高い相関が みられるよらで尿管口の形態観察が手術適応を決める判 定基準になりらることが示された。

\section{手術方法ならびに手術成繶}

Primary VUR に対して手術療法を行つたのは46例中 37例，51尿管であり，手術をみあわせたのは 9 例で全て 6歳以下の幼小児例であつた. Secondary VUR では27
Table 11 Operation for affected ureters

\begin{tabular}{l|c|c}
\hline \multirow{2}{*}{} & \multicolumn{2}{|c}{ No, of Patients (Ureters) } \\
\cline { 2 - 3 } & $\begin{array}{c}\text { Primary } \\
\text { VUR }\end{array}$ & $\begin{array}{c}\text { Secondary } \\
\text { VUR }\end{array}$ \\
\hline No operation & 9 & 20 \\
\hline Operation & 37 & 7 \\
\hline Paquin & $8(12)$ & $3(3)$ \\
\hline $\begin{array}{l}\text { Politano- } \\
\text { Leadbetter }\end{array}$ & $26(36)$ & $3(3)$ \\
\hline $\begin{array}{l}\text { Nephro- } \\
\text { ureterectomy }\end{array}$ & $2(2)$ & $1(1)$ \\
\hline $\begin{array}{l}\text { Uretero- } \\
\text { ureterostomy }\end{array}$ & $1(1)$ & 0 \\
\hline
\end{tabular}

例中 7 例， 7 尿管に対して手術療法を行つた.のこりの 20例では逆流防止手術は行わなかつたが，らち11例に原 疾患に対する手術療法を行つた（表11）。 Primary VUR では Paquin 法（以下P法）8例，12㽷管，PolitanoLeadbetter 法（以下 P-L 法）26例，36尿管でありほか に腎機能が荒廃していたため腎摘除術施行したもの 2 例，完全重複尿管の 1 例では，VUR のある下半腎をド レンする尿管を，VUR のない上半腎をドレンする尿管 に端側吻合をした. Secondary VUR ではP 法と P-L 法 がそれぞれ 3 例， 3 尿管あり，1 例は腎摘除術を施行し た。

症例 $2: 33$ 歳男子, 会社の健康診断 で高血圧で蛋白 尿を指摘され精査目的にて慶応病院内科に入院した。 IVP にて左萎縮腎, 右腎盂結石をみとめたが (困 7), renin-angiotensin 系に異常はなく腎動脈造影からも腎血 管性高血圧は否定された。排尿時膀胱造影によつて左萎 縮腎に VUR が証明され（図8），泌尿器科転科となり， 右腎盂切石術にひきつついい P-L 法により左尿管逆流 防止術を施行した。術後左腎機能は良好に保たれてょり （図9)，VUR は消失した（図10），術後も高血圧は持 続しているが食事療法のみでュントロールされている。

P法と P-L 法の優劣について, いくつかの観点から 比較検討してみた（表12）.難易度をみるために手術時間 と出血量の平均値を比較したが，手術時間には差がなか つた。出血量は P-L 法がP 法よりも多いという結果が 出たが，これはP法が主として小児に行われたことによ るものであつて P-L 法が難かしいために出血量が多く なつたというわけではない，術後経過を比較するために 尿管スプリントと膀脱留置カテーテルの留置期間及び術 後退院までに要した日数を比較したが，いずれにも差は なかつた。最近施行した P-L 法で尿管スプリントを留 
Fig. 7 Case 2. Preoperative IVP

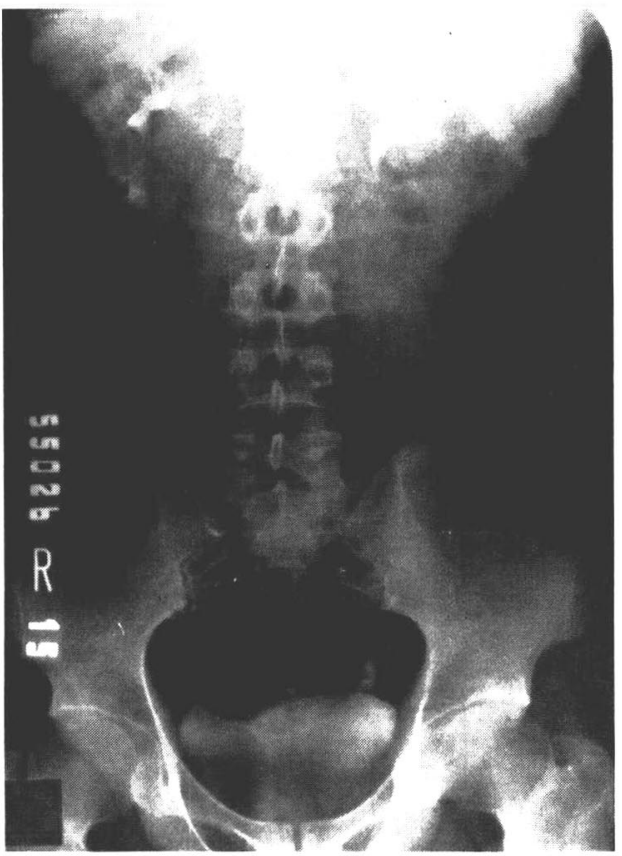

Fig. 9 Case 2. Postoperative IVP

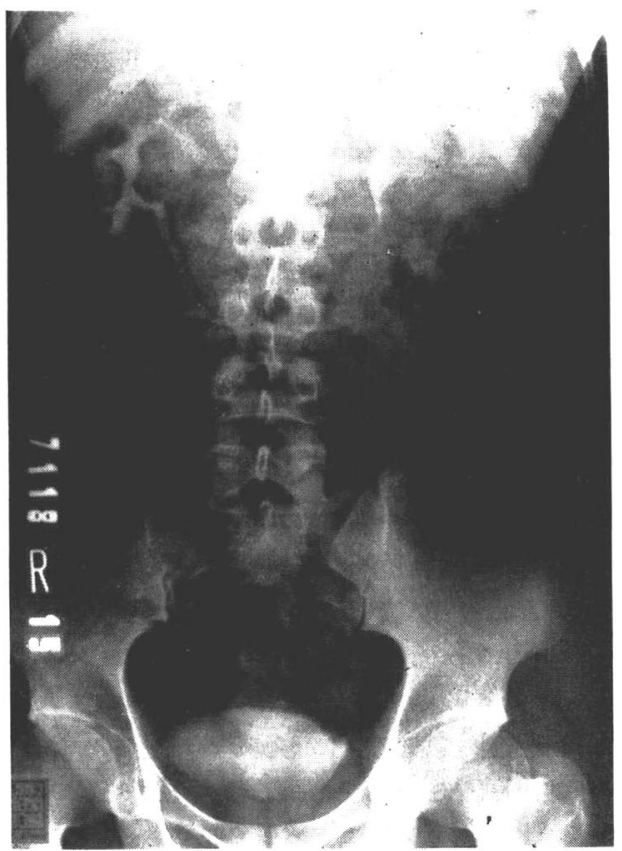

Fig. 6 Case 2. Preoperative voiding cystogram

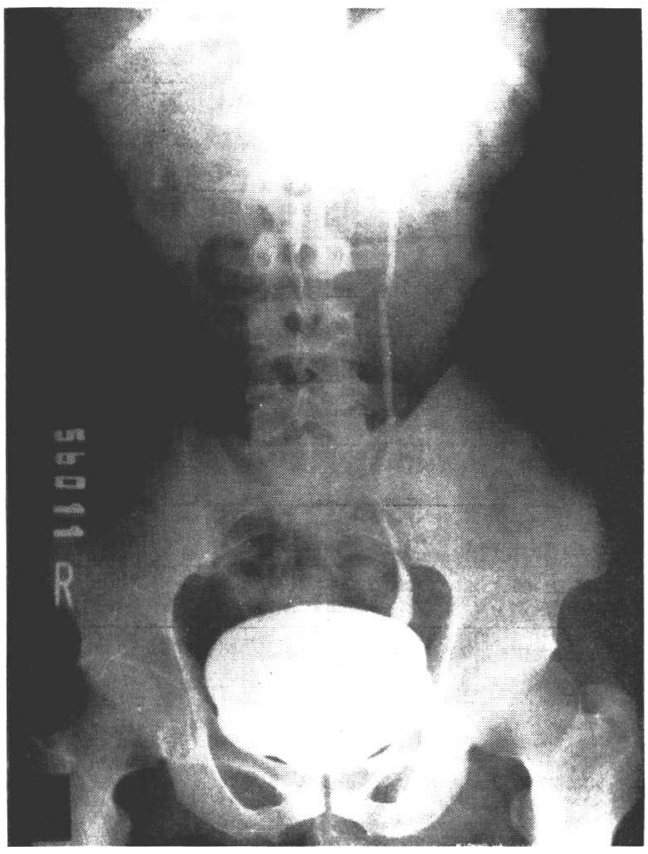

Fig. 10 Case 2. Postoperative voiding cystogram

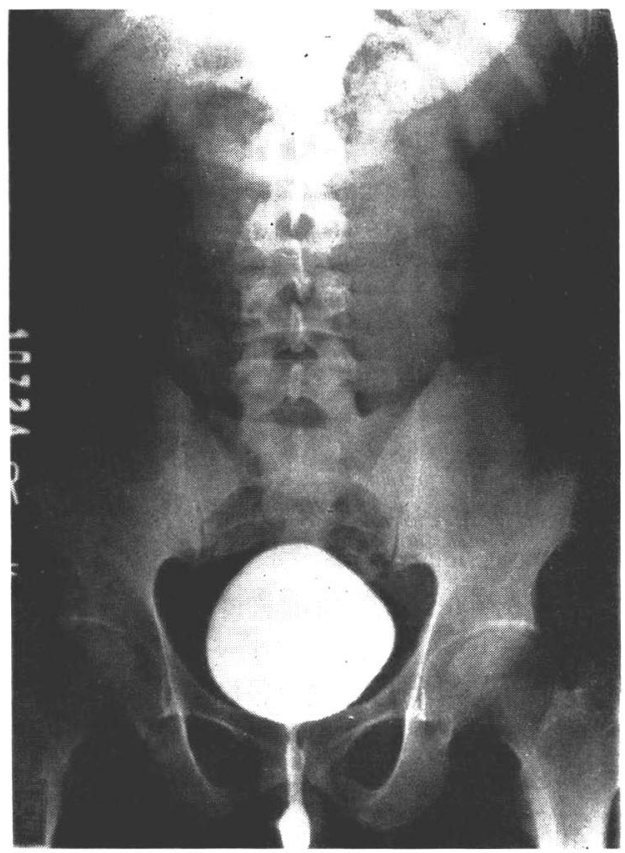


Table 12 Paquin vs Politano-Leadbetter

\begin{tabular}{l|c|c}
\hline $\begin{array}{c}\text { Duration of operation } \\
\text { (hours) }\end{array}$ & Paquin & $\begin{array}{c}\text { Politano- } \\
\text { Leadbetter }\end{array}$ \\
\hline Unilateral & $2^{\circ} 58^{\prime}$ & $2^{\circ} 03^{\prime}$ \\
\hline Bilateral & $2^{\circ} 51^{\prime}$ & $3^{\circ} 04^{\prime}$ \\
\hline Blood loss (ml) & 150.0 & 211.6 \\
\hline Unilateral & 152.5 & 446.5 \\
\hline Bilater ral & 5.0 & $4.4^{*}$ \\
\hline $\begin{array}{l}\text { Duration of stent catheter } \\
\text { (days) }\end{array}$ & 10.8 & 10.9 \\
\hline $\begin{array}{l}\text { Duration of transurethral } \\
\text { catheter (days) }\end{array}$ & 20.3 & 20.0 \\
\hline $\begin{array}{c}\text { Hospital stay } \\
\text { (days) }\end{array}$ & 9.0 & 10.3 \\
\hline $\begin{array}{l}\text { Incidence of post operative } \\
\text { complication (\%) }\end{array}$ & & \\
\hline
\end{tabular}

* 3 patients, stent free, excluded

置しなかつた 4 例はいずれも術後経過良好であつた。

術後の早期合併症はP 法で 1 例 $(9.0 \%)$ 飞創感染,

P-L 法で 3 例 $(10.3 \%)$ 飞創感染, 創離開, 術後貧血が

みられたがいずれも重篤なものではなかつた。

術後 1 年以上, 経過観察しえた primary VUR 24 例, 37尿管について IVP 上にみら机る hydronephrosis， hydroureter の手術前後汇执引る推移を観察した。術直 後の IVPは7-10日目に撮影しているが，術前の所見 を問わず，術後のIVP で所見に変化のなかつたもの は18尿管, 所見が改善されたものは 9 尿管, 逆に悪化し たものは10尿管であつた。機能喪失の例はなかつた。術 後 3-6 カ月での再検では34尿管はほぼ正常に復してお り，2 尿管は軽度の尿管拡張を残すの久となつていた。 これも 1 年後には活济正常像を示したが，のこりの 1 疗 管は 1 年後の IVP 飞おいてもなお中等度の hydronephrosis と hydroureter が持続しておう, 失敗例と判定し た $(2.6 \%)$. しかしこの扯例も 2 年後の IVP では改善 がみられた。

術後の排尿時膀胱造影は 3 力月後にとることを原則之 しているが, primary VUR では全例逆流現象は消失し ていた. 24例中 6 例は例外的に術後 2 週間で検查をした が，いずれも逆流現象はみられなかつた。1 年以上の経 過観察で再発あるいは対側腎に VUR が出現した症例は ない。

以上まとめると primary VUR 37尿管の手術成績は 1 年後にな和尿管閉塞症状が見られた 1 例をのぞいて97.3
\%の成功率であつた。一方 secondary VUR では P-L 法施行の 1 例は術後も逆流現象が持続したため膀脱瘦を 浩設した。さらに 1 例はP 法施行後 1 年目の IVP でな お hydronephrosis, hydroureter が残つていた。のこり 4 例は逆流現象が消失し，X線学的にも改善がみられた。 䍜患尿管に対する手術を行わなかつた20例のらち原疾患 に対する手術を行つたものが11例，保存療法で経過観察 を行つたものが 9 例であつた。保存療法施行症例のらち で化学療法開始後 1 年目でなお VUR が証明されたもの 1 例，腎不全で死亡したもの1例であるが，他は拉拉む 权治療に反応し，VUR による臨床症状はコントロール された。しかし経過観察としての排尿時膀胼造影を行つ ていないので VUR 消失の効果については判定できなか つた。

\section{考按}

統計的事項：慶大泌尿器科に打ける過去 10 年間の VUR 症例は 73 例で，同期間入院患者総数の $2.1 \%$ に相当 する゙.男女比をみると primary VUR では約 3 対 1 で圧 倒的に女子に多い，女子に多いことは諸家の報告と一致 するところであり，之くにわが国の文部省科研総合研究 (班長, 新島端夫教授) の成績 ${ }^{5)}$ とは，近似していた。 Lenaghan et $\mathrm{al}^{6)}$ によれば尿路感染症の頻度に並行して 幼児期には男子に多く，小児期には女子多くなると報 告されているが，われわれのシリーズでは幼小児期の 症例が少いので比較検湖は行い兑なかつた. Secondary VUR では原疾患による男女差は明らかであるが，全体 としての症例数では男女差はみら机なかた。

Primary VUR は secondary VUR と較べて両側性の

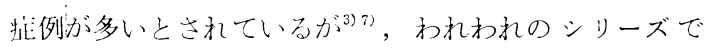
も峏側性症例が $42 \%$ 占めた. Primary VUR には両側 性発生が多いことと, X 線学的検查で片側性であつても 1 回の検查では対側婜のVURを否定できないという事 実から罹患尿管の診断には慎重であらねねばならない。一 j secondary VUR では両側性症例が17\%と比較的少な からた.

男子の primary VUR では33歳が最高㱓者であつた。 Brannan et al. ${ }^{8)}$ によ165例 の報告でも13歳以上の症 例はなかつたという，成人男子には primary VUR が少 いことは事実であり，診断を下すまでには secondary VUR，とくに下部尿路障害について十分に検討しておか ないと治療方針を誤ることにもなりかねない。

VUR が非閉塞性尿路感染症の原因となり放置すれば 末期腎不全にも抒ちいることは広く指摘されるところで 
ありまた末期腎不全になつてからでは逆流防止手術を 行つても臨床的改善はのぞめないっことから, VUR に も早期診断, 早期治療が要求されることは異論のないと ころであるが，いかゆる sterile VUR の発見はむつか しい.われわれのシリーズでは蛋白尿又は顕微鏡的血尿 のみを初発症状として，自覚症状を全くともなわない症 例がそれぞれ 3 例と 2 例あつた. 小川の報告 ${ }^{10)} て ゙ も 44$ 症 例のらち血尿又は蛋白尿を初発症状とするものがそれぞ れ 3 例と 1 例あつた。こうしたことから血尿又は蛋白尿 の診断にはVUR の検索を加えることが必要であり，ま たこれらが VUR の早期発見に大いに役立つるのである と考㝋られた。症例 1 で述べたように逆流防止手術によ つて䫓微鏡的血尿も消失しているので VUR が血尿の原 因であると結論できるであろらが，その発生機序はな 颃不明である. Uy et al. ${ }^{11)}$ はVUR に合併した viral sterile hemorrhagic cystitis 1 例報告をして viral infection と VUR 合併の意義について言及しているが，わ れわれの症例では, ウイルスの検索は行つていない。

Lyon et al.`は小児 VUR 症例の膀朕鏡的観察から 尿管口の形態と位置が VUR の発生率と高い相関を示し ており，保存療法で自然治瘉する症例をあらかじめ選別 することもできることを報告した。このことは成人に拉 ける非閉塞性尿路での慢性腎盉腎炎の原因としてたと兄 VUR が証明されなくても，尿管口の形態と位置の観察 から幼小児期にあつたであろう VUR の結果であると推 論する間接的証明になつている 景となつて VUR 症例では尿管口の形態と位固を観察す ることが routine work となつている.しかしこれには 異論がないわけでもない，尿管口の位置観察には主観が 入る久点を指摘し ${ }^{13)}$, 形態観察は予後判定に不必要であ るとする報告がある(14)．また submucosal tunnel の長さ をより重視する報告すある 口の位置観察には再現性に難点が感じられた。尿管口の 形態と Dwoskin \& Perlmutter の分類 ${ }^{3}$ にる VUR の grade との相関について検討した結果では, primary VUR にはある程度の相関はみられるものの尿管口の形 態から VUR の grade を推定し, 予後判定に役立たせ ることには無理があるように思われた。さらに後述する ように成人の VURは原則として手術適応と考学ている ので尿管口観察の意義は高くない. Secondary VUR に おいてはより高い相関がみられ手術適応を決める参考資 料になりらると云えるが，やはり尿管口の形態と位置観 察の意義は幼小児 VUR の手術適応をきめることにある
と理解するのが妥当であろら.

VUR の手術適応について：1960年代初頭に Hutch ${ }^{16)}$ をはじめ多くの泌尿器科医によつて, 非閉塞性尿路での 慢性腎盃腎炎の原因が VUR による上行性感染であると 指摘されて以来, VUR への関心はたかまり，手術的治 療への積極的努力が厸われその成績は大いに向上した。 Scott（1969）の報告 ${ }^{17)}$ では逆流防止手術の不成功例は VUR の持続したもの $10 \%$ ，尿管閉塞を来たしたもの 4 \%であり，さらに最近では多くの施設で100\%に近い成 功率をあげている，このように手術成績が良くて，しか も grade がすすんでからではやはり成績がおちる ${ }^{18)}$ とい らことから VUR に対する早期からの積極的手術療法が の呑まれるわけであるが, 反面小児の primary VUR で は身体の成長とともに膀胖三角部が解剖学的に成熟する につれて，との22-42\%が自然に消失すると報告されて 抢り ${ }^{8) 19) 20)}$ ，手術適応関する議論が分れるところであ る.膀胀鏡的観察による尿管口の形態と位置を重視する ものから ${ }^{4)}$, Dwoskin \& Perlmutter の分類による VUR の grade によつて適応を決め, intra-renal reflux は絶 対的適応とするもの ${ }^{21)}$, さらに以上の事項に臨床的腎孟 腎炎の既往歷の有無と，IVP 所見を加えた score をと り, 点数の多頞によつて適応を決めようとするすの ${ }^{222}$, 尿管払張の程度を重視するもの ${ }^{23)}$ ，年齢を問わず全て, まず化学療法を行つてみて再発したものに手術を行うも の 以下の手術は避けた方が良いと述べている.われわれの シリーズでは小児例が少くて, 小児の VUR の手術適応 に関する検討は意図するところではないが，6歳以上で grade II 以上の VUR であれば一次的に手術適応と考兄 ている.

成人の primary VUR の手術適応を決めるらえで問題 なのは，腎監炎をともなら VUR が果して抗生物質 による保存療法のみで治癒するものなのか否か, また尿 路感染症をともなわないいわゆる sterile VUR を手術 する必要があるのか否かという2 点である. 前者に関し ては一部に保存療法のみで治癒する症例もないわけでは ないが，自然消失の原因が Hutch ${ }^{20)}$ の云うように膀脱 三角部の解剖学的成熟にあるとすれば, 成人の VUR が 自然治癒することは考兄にくく，たしかに保存療法に よつて改善のみられる症例も, 治療期間中に限られるこ とが多く，治療を中止すれば結局は腎㙉腎炎を絽返すこ とになるわけで(9)，VUR の grade にかかわらず全て逆 流防止手術の適応であると考学る，後者に関しては， 
sterile VUR が腎機能障害をもたらすか否かについて賛 否両論ある。一方ではVUR があつても感染をともなわ なければ腎機能障害が来ないので手術の必要性はないと している ${ }^{826)}$ ．小川は腎機能にとつて有害な逆流と無害 な逆流の 2 種類あることを指摘している(10). 他方末期腎 不全患者の原疾患を retrospective に観察した結果では sterile VUR る腎機能障害の原因になりらることが指摘 されている29). Salvatierra, Jr. \& Tanagho') はこれを retrograde water hammer effect と述べている. したが つてたとえ sterile VUR でも手術の適応ありとする考 えであるが，われわれもこの説を支持するものであり， 症例 1 に紹介したような無症候性顕微鏡的血尿，あるい は尿蛋白のみを初発症状とする sterile VUR に逆流防止 手術を施行して良い結果を得た。

今後 VUR の手術適応はますます增兄ていくものと 思われるが，症例 2 に供覧したよらな萎縮腎にともな ら VUR の手術適応はどうであろらか. 先天性疾患であ る VUR が発育不全腎を合併してくることは充分考兄 られることで27), 発育不全腎あるいは萎縮腎にともなう VUR 症例はけつして稀れなものではない. Woodard \& Keats $^{28)}$ の幼小児例では逆流防止手術を施行した217例 中44尿管にX線上腎実質の萎縮像があつたと報告されて いる. かかる症例での手術成績関する情報は欠けてい るが, 症例 2 のらに IVP にて造影されるだけの腎機 能を維持していれば，まず腎保存の手術を考えるのが原 則であると考える。

片側性 VUR の術後に反対側の尿管に VUR が出現し たといら症例が少なからず報告されている。したがつて たと六片側性 VUR であつても対側尿管口の形態, 位置 に異常がある場合には両側の逆流防止手術を行うべきで あるとする報告がある ${ }^{29)}$. しかしこのような VURは一 過性のもので特別の治療を要しないものが多い. ${ }^{21)}$. いか に合併症の少い手術とは云光，不必要な手術をすること の危険珄を考学われわれはVUR が証明された尿管のみ を手術することを原則としている．ただし，反対側に VUR が無いことを証明するためには複数回の検査を行 つて慎重に判断することが大切であることはいうまでも ない，幸いわれわれのシリーズでは術後反対側に VUR が出現した症例はない。

臨床的に多くみられる secondary VUR の原疾患は前 立腺肥大症をはじめとする下部尿路閉塞と, 神経因性 膀脂である. 前立腺肥大症 の $0-14 \%$ VUR が 合併 したとの報告があるが，多くは原疾患に対する手術療
法のみで十分であり，逆流防止手術の必要はないとさ れている ${ }^{30)}$.われわれのシリーズも前立腺肥大症によ る secondary VUR で逆流防止手術を施行した症例はな い. 神経因性膀脱に発生した VUR に対する逆流防止手 術にはこれまで否定的意見がつよかつたが，最近はこの 領域でる症例を選べば逆流防止手術によつて良い結果が 得られることが報告されるようになつた ${ }^{3132)}$. われわれ もこれに同意見であるがまだ症例数が少くて検討を加え る段階ではない。

手術成績に関して：現在ひろく用いられている手術方 法は P-L 法, P法, Hutch I 法, distal tunnel 法な どであるが，手術法の選択はともかく，慣れた方法でや れば，いずれの方法でも満足すべき結果が得られてい る21) われわれのシリーズでは P-L 法とP法に限られ ているが，両者間に手技的にも，手術成績においても差 はなかつた. ただ Garrett \& Schlueter は3 歳以下の幼 児例には P-L 法は適当でないと述べている ${ }^{17)}$.

術前, 感染症の有無は手術成績を左右する要素となる が, 感染症のコントロールは比較的容易である.むしろ 手術直前に逆行性造影, 内視鏡検查など感染症を増覀さ せるような検査を避けることが大切であるう。

尿管スプリントカテーテル留置の意義については尿管 屈曲防止のために欠くべからざるものであるとの意見も あるが33)，術直後の尿流出に不安のある症例だけに用い れば良いとの意見もある ${ }^{34)}$.われわれのシリーズでも片 側性 VUR の 4 例に尿管スプリントなしで手術を施行し たが，結果はいずれも良好であつた。

逆流防止手術の不成功例としては持続する VUR と 尿管閉塞がある。したがつて手術成績の判定には術後 の IVP と排尿時膀胼造影は不可欠の検査法であるが, その実施時期に関しては施設による不一致がある.われ われは術後 7ー10日目に IVPを行つている. この時 期の IVP の目的は手術側腎機能を確認することであ つて, 尿管閉塞の程度によつて手術成績を判定すること はできない，この時期にはまだ術後の浮腫や感染症の影 響がとれずに拡張像を示すものがある. Postoperative dilatation が可逆性のものであれば 6 週ないし 3 カ月後 には改善されるものであり ${ }^{735)}$, 術後 7-10日目の IVP で hydronephrosis, hydroureter のあるものは 3 カ月後に 再検してな和明らかな払張像のあるるのは不成功例と判 定する. 同様に術後の浮腫, 感染症は一過性の VUR の 原因となるので術後の排尿時膀羘造影実施時期が問題で ある、施設によつてまちまちであるが2836)，われわれは 
3カ月後の検査によつて手術成績を判定した。しかし VUR の性格上 1 回の検査で証明されなくても治癒とは 云いきれない面もある.術後 $2-3$ 年に数回検査する必 要性を強調する報告もある ${ }^{35)}$ 。また $\mathrm{Amar}^{37)}$ は術後 5 年 目の晚期再発例を報告し, 少くとも5 年間の経過観察に よつて治癒判定を行うべきであると述べている.

\section{結語}

1968年 1 月より1977年12月までの 10 年間に慶大泌尿器 科学教室で経験した73例の VUR 症例につき臨床的検討 を行い文献的考察を加穴た。とくに primary VUR に打 いて P-L 法，P法の手術成績の良好なることを報告し （手術成功率 $97.3 \%$ )，また成人の primary VUR に対す る手術適応関するわれわれの考えを述べた。

\section{文献}

1) Hutch, J.A., Chisholm, E.R. and Smith, D.R.: Summary of pathogenesis of, and new classificarion for urinary tract infection (and a report of 381 cases to which this classification has been applied). J. Urol., 102, 758-761, 1969.

2) Salvatierra, O. Jr. and Tanagho, E.A.: Reflux as a cause of end stage kidney disease: Report of 32 cases. J. Urol., 117, 441-443, 1977.

3) Dwoskin, J.Y. and Perlmutter, A.D.: Vesicoureteral reflux in children: A computerized review. J. Urol., 109, 888-890, 1973.

4) Lyon, R.P., Marshall, S. and Tanagho, E.A.: The ureteral orifice: Its configuration and competency. J. Urol., 102, 504-509, 1969.

5) 新島端夫 : 文部省科研総合研究, VUR 研究班 に和ける非閉塞性 VUR の追跡調査成績につい て. 日泌尿会誌, 68, 854-855，1977。

6) Lenaghan, D., Whitaker, J.G., Jensen, F. and Stephens, F.D.: The natural history of reflux and long-term effects of reflux on the kidney. J. Urol., 115, 728-730, 1976.

7) Garrett, R.A. and Schlueter, D.P.: Complications of antireflux operations: Causes and management. J. Urol., 109, 1002-1004, 1973.

8) Brannan, W., Ochsner, M.G., Rosencrantz, D.R., Whitehead, C.M. Jr. and Goodier, E.H.: Experiences with vesicoureteral reflux. J. Urol., 109, 46-48, 1973.

9, Bakshandeh, K., Lynne, C. and Carrion, H.: Vesicoureteral reflux and end stage renal disease. J. Urol., 116, 557-558, 1976.

10）小川秋実: 膀胱尿管逆流の臨床経過. 日泌尿会 誌, 65, 520-526, 1974.
11) Uy, G.A., Khan, A.J. and Evans, H.E.: Vesicoureteral reflux complicating sterile hemorrhagic cystitis: A case report. J. Urol., 115, 612, 1976.

12) Vermillion, C.D. and Heale, W.F.: Position and configuration of the ureteral orifice and its relationship to renal scarring in adults. J. Urol., 109, 579—584, 1973.

13) Deture, F.A. and Walker, R.D.: Measurement of the distance from the ureteral orifice to the bladder neck: Additional objective data in the cystoscopy of patients with reflux. J. Urol., 112, 326, 1974.

14) Manley, C.B., Neuman, N. and Mcalister, W.H.: Prognosis for resolution of moderate, primary reflux in girls. J. Urol., 115, 307-309, 1976.

15) Cass, A.S. and Ireland, G.W.: Significance of ureteral submucosal tunnel length, orifice configuration and position in vesicoureteral reflux. J. Urol., 107, 963-965, 1972.

16) Hutch, J.A.: Vesico-ureteric reflux, role in pyelonephritis. Amer. J. Med., 34, 338-349, 1963.

17) Scott, J.E.: Results of anti-reflux surgery. Lancet, 2, 68-71, 1969.

18) Glenn, J.F. and Anderson, E.E.: Technical considerations in distal tunnel ureteral reimplantation. J. Urol., 119, 194-197, 1978.

19) Senoh, K., Iwatsubo, E., Momose, S., Goto, $M$. and Kodama, H.: Non-obstructive vesicoureteral reflux in adults: Value of conservative treatment. J. Urol., 117, 566-570, 1977.

20) Hutch, J.A.: Theory of maturation of the intravesical ureter. J. Urol., 86, 534-538, 1961.

21) Ahmed, S.: Ureteral reimplantation by the transverse advancement technique. J. Urol., 119, 547-550, 1978.

22) Edelbrock, G.G. and Mickelson, J.C.: Selection of children for vesicoureteroplasty. J. Urol., 104, 342-345, 1970.

23）寺島和光, 福岡 洋: 小児原発性膀腃尿管逆流 の尿管像. 泌尿紀要, 20, 529-532，1974.

24) Herberman, H.G., Markman, I. and Payne, R.A.: Vesicoureteral reflux requiring ureteroneocystotomy. J. Urol., 101, 833-835, 1969.

25）新島端夫, 藤田幸利: 膀脂尿管逆流現象 (VUR) 腎と透析, 2, 163-168, 1977.

26) Shopfner, C.E.: Vesicoureteral reflux. Fiveyear re-evaluation. Radiology, 95, 637-648, 1970. 
27) Stecker, J.F. Jr., Rose, J.G. and Gillenwater, J.Y.: Dysplastic kidneys associated with vesicoureteral reflux. J. Urol., 110, 341-343, 1973.

28) Woodard, J.R. and Keats, G.: Ureteral reimplantation: Paquin's procedure after 12 years. J. Urol., 109, 891-894, 1973.

29) Warren, M.M., Kelalis, P.P. and Stickler, G.B.: Unilateral ureteroneocystostomy: The fate of the contralateral ureter. J. Urol., 107, 466-468, 1972.

30) Kogan, S.J. and Freed, S.Z.: Postoperative course of vesicoureteral reflux associated with benign obstructive prostatic disease. J. Urol., 112, 322-325, 1974.

31) Jeffs, R.D., Jonas, P. and Schillinger, J.F.: Surgical correction of vesicoureteral reflux in children with neurogenic bladder. J. Urol., 115, 449-451, 1976.

32) Hackler, R.H.: Modified Hutch I vesicoureteroplasty in paraplegia. J. Urol., 118, 953-
954, 1977

33）板谷宏柣，園田孝夫：膀胱尿管逆流飞対する Politano-Leadbetter 膀脱尿管形成術について. 泌尿紀要, 20, 843-847, 1974.

34) Nanninga, J., King, L.R., Downing, J. and Burden, J.J.: Factors affecting the outcome of 100 ureteral reimplantations done for vesicoureteral reflux. J. Urol., 102, 772-777, 1969.

35) Senoh, K., Iwatsubo, E. and Momose, S.: Followup study after conservative and surgical treatment of vesicoureteral reflux. J. Urol., 119, 199-201, 1978.

36) Glenn, J.F.: Urologic surgery. 2nd ed., P. 272, Harper \& Row, Publishers, Inc., Mary. land, 1975.

37) Amar, A.D.: Delayed recurrence of reflux after initial success of antireflux operation. $J$. Urol., 119, 131-133, 1978.

（1978年11月27日受付） 